\title{
Exiles Turn Lemons Into Lemonade: Multiethnic Poets of the US Crossing Borders
}

\author{
Mais Qutami \\ Amman Arab University, Amman, Jordan
}

\begin{abstract}
This study critically examines selections from the political poetry of African American writer Amiri Baraka (Le Roi Jones) and Arab American writer Suheir Hammad and the path they have chosen for themselves as exiles reflected in their writing. Edward Said's theory of exile is employed to illuminate common areas of interests that link the two writers together as exiles. The study reveals their attitude toward various issues that impact both races, the African American and Arab American such as imperialism, colonization, and oppression. Their poetry underlines the impact of capitalism and racism on US society and other nations disempowered by imperialism.
\end{abstract}

Keywords: exile, African American, Arab American, Edward Said

\section{Introduction}

It is not a surprise that multiethnic communities reach out to each other and form bonds that help them overcome difficulties faced in society. For instance, the status of Arab Americans as non-white, and outside the mainstream, has led many to seek relations and build links to other groups of color such as African Americans. Long before September 11, 2001, both communities have experienced a shared oppression that took the shape of "racial profiling, detention and murder for political organizing or even for the suspicion of political organizing” (Hartman, 2006, p. 146). Arab Americans were forced, as Majaj (2008) saw it, due to political events, from the 1967 war in the Middle East to 9-11 and beyond, to deal with the issue of identity and the "write or be written" imperative: "Define yourself or others will define you". This has been the same dilemma African Americans and other minorities have encountered throughout history. Although the shared oppression connects the two communities to each other, the status of Arab Americans has become more problematic since September 11, 2001. African Americans, however, have sensed an improvement in their situation as racism against them was being deflected to people of Middle Eastern descent. In one standup comedy performed in D. C. a comedian states, "Black people, we have been delivered. Finally, we got a new nigger. The Middle Easterner is the new nigger", and another remarks, "It's a good time to be Black. If you ain’t got no towel wrapped around your head, your ass is in the game!” (Jacobs-Huey, 2006, pp. 60-61).

This reality demonstrates the link between the African American and Arab American community as they both suffered from racial discrimination and persecution due to their skin color and place of origin. They have both been viewed as suspects for crimes they had no connection to. Sadly, they have a shared history of pain and discrimination. But intellectual exiles such as Baraka and Hammad, each representing his/her community, have set the goal for themselves to write, and through their writing, inspire and empower others to resist

Mais Qutami, Ph.D., Assistant Professor, Department of the English Language \& Translation, Amman Arab University. 
submission and participate in their battle for justice and social transformation.

Like Baraka was enraged by all the racism blacks had faced in the 1960s, Hammad developed feelings of anger toward American policies and its racism against minorities. Baraka and Hammad have used their poetry as tools in their struggle for justice and transformation. They both resist and attack hegemonic forces that oppress people and contribute to their suffering. Both write angry poetry to provoke readers, disturb their peace, and make them think and act not giving anyone an excuse that allows them to sit on the sidelines and watch others suffer. They believe that silence is complicity and approval of the violence that occurs against humanity. In “Black Art”, Baraka (1969) writes:

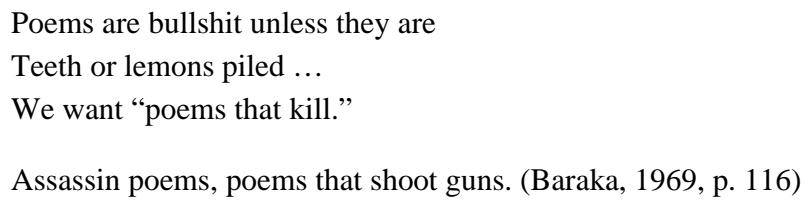

Baraka realizes the power of words and poetry that can make a difference in the world. He strongly believes in poetry's impact on people, and so calls for revolutionary poems that fight, "poems that kill". Hammad, on the other hand, holds the same belief, as Baraka, in the role poetry has in terms of bringing change and transformation to the world. Hammad (1996) explains:

Why do I write? 'Cause I have to. 'Cause my voice, in all its dialects, has been silenced too long. 'Cause women are still abused as naturally as breath. Peoples are still without land. Slavery exists, hunger persists and mothers cry. My mother cries. Those are reasons enough, but there are so many more. (p. ix)

Hammad writes to give voice to the oppressed and to resist the many attempts to silence the victims and prevent them from speaking up against dictatorship and imperialism. She is determined to make the voices of women, refugees, slaves, and the downtrodden heard in the world. This drive to subvert existing political and social paradigms to uplift the subjugated and improve their life conditions is what links the two writers, Hammad and Baraka, to each other as intellectual exiles who have chosen this path of activism and marginality at the same time.

\section{Edward Said's Theory of Exile}

Exile is the banishment and separation of an individual from his native land due to certain political circumstances that have forced a person to depart. This painful condition of exile has been a recurring theme in Edward Said's critical works. His focus on the issue comes from his personal experience of separation from his homeland Palestine. There is this actual experience of an exile who suffers from displacement, poverty, violence, and humiliation which the intellectual exile has not really gone through. This may have been the condition of many Palestinians in 1948 after they lost their land but intellectuals such as Said did not have to overcome the same conditions because he experienced the ramifications of exile and not exile itself. Due to the exile of his ancestors and people, Said (1993), like many others, lived his life in a state of "metaphorical" exile as he calls it. It relates to the intellectual standpoints an exile holds and a condition that can be practiced by individuals who have not experienced actual exile. Said did not have to experience actual exile first hand but through the loss of Palestine and his family's history which was shaped by their displacement and dispossession, he felt the suffering and trauma vicariously as other exiles have such as Suheir Hammad and other Arab Americans. 
The concept of metaphorical exile can be applied to Hammad and Baraka as they both live outside the mainstream and neither have a homeland to return to. Hammad cannot return to Palestine as Baraka is unable to return to an Africa he never knew. They share the life of the intellectual exile as they bear the consequences of the historical displacement of their people even if they have not experienced it firsthand. Perhaps those who went through the actual experience of dispossession and exile are unable to articulate their emotions or turn that pain into words. But distance and relative detachment from the experience brings these writers closer to it as they engage in writing about it and telling the stories of those who have struggled terribly like their parents and ancestors. Their daily experiences that bring their identities to the foreground complicates their lives and their identities. Their dual identities present a challenge; to be Arab/Muslim and American has become undesirable since 9/11, while being Black in America is also problematic. Hammad and Baraka do not try to seek comfort, accommodation, or acceptance by the mainstream, on the contrary, they aim at unsettling people and disturbing their peace by exposing injustices in society and in other countries. They expose people to worlds they are unfamiliar with and perhaps never heard of or seen before. They also connect the suffering of many Americans inside the borders of the USA to those in the Third World. Said (1993) explains:

Exile is a model for the intellectual who is tempted, and even beset and overwhelmed, by the rewards of accommodation, yea-saying, settling in. Even if one is not an actual immigrant or expatriate, it is still possible to think as one, to imagine and investigate in spite of barriers, and always to move away from the centralising authorities towards the margins, where you see things that are usually lost on minds that have never travelled beyond the conventional and the comfortable.

Baraka's status as an exile draws him to write the highly controversial poem "Somebody Blew Up America” through which his options of accommodation and settling in have become extremely limited. He chooses not to please the authorities when he doubts it was Arab terrorists who were responsible for the 9/11 attacks. The poem, in general, takes readers out of their comfort zone and forces their minds to "travel beyond the conventional".

Hammad, as an exile, is also far from accommodating and yea-saying, she does not take things for granted as others may. She is skeptic about the security measures implemented at US airports in order to prevent terrorist attacks. In her powerful poem "Mike Check", she does not approve of the way Arabs or Muslims are treated as suspects and terrorists based on their place of origin or skin color. She also makes a reference to the murder of Red Indians by the Americans who treat others as terrorists forgetting their own crimes against a certain people at a certain time in history. Hammad (2005) ends her poem with, “a-yo mike/whose gonna/check you?”. This poem indicates that appeasing authorities is not a priority at all for Hammad. She even makes it a point to mention the Red Indians' tragedy as a reminder of a history many wish to erase or turn a blind eye to. Naturally, a reminder as such is unsettling for many American readers, makes them uncomfortable, and forces them to face that reality and people's remembrance of it. Both writers have written poetry that is inspiring and empowering at the same time. Their work has certainly moved them from the "centralizing authorities towards the margins" where they were able to explore and look into unusual situations in the mainstream and the margins simultaneously.

This intellectual exile because of his/her views and inherited sense of exile, according to Said (1993), has chosen to live outside the mainstream, unaccomodated, unadjusted, and detached but at the same time very involved. Both writers live in relative detachment that allows them to see beyond the common and the known and whose judgment cannot be clouded by their own personal involvements because they have chosen to live outside every mainstream and the limits it imposes on its followers. Hammad, for example, is different from most Arab Americans who for a long time were focused on passing as white and trying to integrate into white 
society. Growing up in Brooklyn, she found herself developing a sense of belonging to a community of people of color and the lower class. She states, "I was a part of colored kids who were being taught by white teachers. So there was a specific animosity towards me from certain teachers because I was Palestinian, but in general we were all in the same boat” (Knopf-Newman, 2006, p. 79). She later became concerned and involved with issues that go beyond the Arab American community and was engaged in a far more universal cause that touched the lives of many minorities such as Blacks, Chicanos, Puerto Ricans, Africans, and Palestinians. Perhaps it is her detachment from Arab Americans that helped her recognize larger issues beyond a single race or ethnicity. She also learns about solidarity with others from June Jordan's poetry and statement "I am now become Palestinian”. Hammad was moved by these words coming from an African American, a non-Palestinian, who recognized oppression and suffering outside her own community and it made her realize that it is not about negotiations, rights, and treaties, it is about humanity and that sums it all up for her (Knopf-Newman, 2006, pp. 77-78). Her status as an exile is also reflected in her lack of accommodation and adjustment to any single community. Hammad notes:

And my father's like you're not Hispanic, you're not black, you're not this, you're not that. And then I'd meet other Palestinians and he'd be like, yeah, but you're not like them either. You know, because it was a very specific immigrant experience at a very specific time... I didn't have the sense of cultural clash in my body. I had it outside of my body... In my body I felt like, I look like everyone else I grew up with—whether they were Puerto Rican or Italian or light-skinned black people. (Knopf-Newman, 2006, p. 85)

Hammad did not belong to a single community but saw herself as a member of a multiethnic one struggling with white male superiority and inequality. Having dark skin and Palestinian roots, she understands others' predicament when dealing with issues of justice. Hammad is able to break the barriers between the oppressed of various cultures and transcend her personal dilemma as an in-between and an outsider, and turn it into a tool of empowerment used to support the subjugated and exploited. This is partially due to her status as an exile who is unsettled by the injustices encountered and determined to unsettle others at the same time. Said (1993) states:

The pattern that sets the course for the intellectual as outsider... is best exemplified by the condition of exile, the state of never being fully adjusted. Exile for the intellectual in this metaphysical sense is restlessness, movement, constantly being unsettled, and unsettling others.

This state of restlessness, constant movement, and unsettling of others by the exile can best be illustrated through the kind of life Baraka has led. Baraka was probably the most radical and polarizing poet in the 1960s and 1960s, who extended political debates to the world of arts (Italie, 2014). He believed that teaching black art and history is essential just as producing works that call for revolution is. There was constant movement in Baraka's life. He graduated from high school and received a scholarship from Rutgers University but feeling out of place there, he transferred to a black college, Howard University, hated it there then joined the Air Force. He was later discharged for having so many books. He also taught at Yale University, George Washington University, and the State University of New York (Italie, 2014). He was always unsettled by the political atmosphere and the conditions African Americans lived in. He became a black nationalist, and leader of the Black Arts Movement, then a Marxist-Leninist. In 1967, he was jailed during the Newark riots. In 1972, he helped organize the National Black Political Convention and founded the Congress of African people. In 2002, Baraka became New Jersey's poet laureate but had unsettled many of his readers through "Somebody Blew UP America" that stirred great controversy and his position was eliminated altogether due to his radical poetry. 
Said emphasizes that exile can be a condition that can be manipulated and turned into a source of great wealth and production of highly fruitful results especially for the oppressed and deprived of proper human rights because of the values the exile strives for as he/she takes on this role in the attempt to make the world a better place. Nevertheless, Said (2002) insists exile is no fun and warns against turning it into a romantic metaphor for the lonely intellectual. He explains "You must first set aside Joyce and Nabokov and think instead of the uncountable masses for whom UN agencies have been created” (Said, 2002, p. 175). Clearly, the thousands of UN agencies and refugee camps around the world were not established to provide the exile a luxurious life, and that is the true reality of the exile. There is nothing romantic or exotic about such conditions. The path Said has chosen for the exile is merely an adjustment and an attempt to deal with the worst condition of loss, displacement, and uprootedness the best way possible.

Said (2002) responds to critics such as Ian Buruma (2001) who accuse him of presenting a rather romanticized version of exile and portraying it as glamorous, sexy, and interesting, saying:

Necessarily, then, I speak of exile not as a privilege, but as an alternative to the mass institutions that dominate modern life. Exile is not, after all, a matter of choice: you are born into it, or it happens to you. But, provided that the exile refuses to sit on the sidelines nursing a wound, there are things to be learned: he or she must cultivate a scrupulous (not indulgent or sulky) subjectivity. (p. 146)

Said's positive view of exile does not come from a belief that exile is something desirable by any means, but since it is not a matter of choice, but a condition some people live in, it must be dealt with. Accordingly, his positive view of it, in spite of its catastrophic impact, is actually an attempt to respond and adapt to the conditions of exile instead of mourning and becoming a helpless victim of a hopeless situation. It provides the individual with an alternative life style that works away from mass institutions that may reject the exile for a situation he did not choose for himself or punish him for being born into it. This is best exemplified through Hammad's experience with exile:

People often want to limit you so if you're Palestinian it's this idea that my exiled refugee status meant that I did not contribute or was not influenced by anything around me. That I'm a static person who because I have a Right to Retum—and I demand it—does not assimilate. It goes back to fundamental racism. (Knopf-Newman, 2006, p. 86)

Hammad asserts that her situation as a refugee or exile does not make her useless to society or unable to contribute but it is racists who portray exiles in that manner because they cannot see beyond this status and what these individuals are capable of.

Said argues that exile can help an intellectual develop a critical perspective and originality of vision, and a distinct worldview as he/she experiences multiple cultures and realities from which new meanings and interpretations can be drawn. Hammad does not fit in Arab American community and neither can she be white. She experienced a certain kind of refugee status and as an exile turned her experience into activism. She has not become a static person paralyzed by the agony of her situation but a Tony award winner and a performer of electrifying poetry on Broadway among many more accomplishments throughout her career. Hammad is a living example of Said's perception of an exile who chose to reshape their lives from being torn and wounded exiles to an insightful intellectual with a vision and a tool that may significantly influence others. Seeing the exile from such a lens can bring some positive aspects of it to the surface regardless of the pain and bitterness it entails. Said (2002) explains the peculiarity of such a situation:

While it perhaps seems peculiar to speak of the pleasures of exile, there are some positive things to be said for a few 
of its conditions. Seeing "the entire world as a foreign land” makes possible originality of vision. Most people are principally aware of one culture, one setting, one home; exiles are aware of at least two, and this plurality of vision gives rise to an awareness of simultaneous dimensions... (p. 148)

Hammad is not white American, black, or a typical Arab either. She does not fit well into Arab American society either but it is this exilic condition that gives her the pleasure of mobility within all these settings and an awareness of different cultures. It is a privilege that creates a plurality of vision, a heightened sense of awareness, and insight most can never gain through living within the confines of society and belonging to a single ethnicity.

Perhaps the human's need for a sense of belonging to a certain place leads the exile to detachment since the ability to go back to one's homeland is not possible. The exile becomes a citizen of the world whose concern is human rights because he/she can no longer commit oneself to a single land or culture. Engaged in larger causes than that of Blacks only, Baraka's concerns extend to other people of color and the poor. Like Hammad, he grew up in a racially mixed neighborhood in Newark which probably explains his engagement with other people of color's narrative and their marginalization by White elite. "He opened tightly guarded doors for not only Blacks but poor whites as well and, of course, Native Americans, Latinos and Asian Americans", the American Indian author Maurice Kenny wrote of him. He adds, "We'd all still be waiting for the invitation from The New Yorker without him. He taught us all how to claim it and take it” (Italie, 2014). Baraka was alienated and exiled in his own homeland as his views and ideologies were considered radical, and thus, rejected by the mainstream. In his poetry, he continuously condemns the hegemonic forces dominating African American community and society in general.

\section{Amiri Baraka: Restless and Controversial Poet}

Amiri Baraka was always a committed activist; committed to struggle, change, unity, and movement (Italie, 2014). He was a black nationalist and then a Marxist who criticized capitalists and imperialists of all colors. In 1974, Baraka rejected Black Nationalism because he thought it was ideologically racist. He later on became focused on political activism, social transformation, and justice (Italie, 2014). Baraka's literary works include the poetry collection "Black Magic", the play "Slave Ship”, and the novel, "The System of Dante's Hell”, among others. He received several grants and prizes, including a poetry award from the National Endowment for the Arts and a Guggenheim fellowship.

Baraka was highly impressed with Malcom X and all he has done to support the African American cause throughout history. Baraka declares "for many of us Malcolm summed up the spirit of the age which was, not only resistance to... White supremacy and imperialism but, ah, aggressive resistance” (Richardson \& Baraka, 1989). He followed his footsteps in resisting White supremacy and "the whole kind of national oppression that Black people were subjected to”. He admired Malcom X for not trying to please any part of the establishment which he viewed as corrupt as well as the Blacks attached to it. Perhaps Malcom X had a great influence on the path Baraka had chosen for himself and the radical poetry he wrote. It was important to him that Malcom X had always told the truth no matter what the consequences were and that set him apart from the "vacillating opportunists, super cautious negroes" who were supposed to represent people like him but would not tell the truth about anything (Richardson \& Baraka, 1989). Baraka himself did not seek assimilation but as an exile preferred a location outside the mainstream.

Baraka was a didactic poet who became popular for his political social comments that were very 
provocative and mostly called for breaking the silence and seeing the truth. Baraka uses poetry as a vehicle for political action. He writes the highly controversial poem "Somebody Blew Up America" which is an attack on racism and the injustices caused by imperialism and violence. He does not choose the common path in his approach to 9/11 and console those who lost loved ones but reacts in anger to what he believes are the causes of such a tragic event. He believes it is US tyranny around the world that brought about the terrorist attacks in 2001. The poem raises questions about the US approach to democracy in other countries that did not result in any progress but in fact more oppression and violence. Baraka (2001) asks, "Who talk about democracy and be lying”. He holds the US responsible for the many wars it has fought to make money, rule the world, gain control over oil resources and then preaches about the good and the evil, democracy, and peace. In one of the lines, Baraka poses the question, "Who got rich from Algeria, Libya, Haiti, Iran, Iraq, Saudi, Kuwait, Lebanon, Syria, Egypt, Jordan, Palestine”. He mentions the Middle East in his poem although he has no Arab roots or connection to the region but sympathizes with these nations whose resources are stolen. As an exile, he consistently highlights injustice wherever he sees it whether it is in his own community or outside of it. Baraka and Hammad, in this respect, build bridges between all the oppressed around the world as they both mention Palestine, Haiti, Nicaragua, the Red Indians among others in their poetry.

Gery (2011) points out that in the first few lines of the poem a "they" is introduced referring to the domestic terrorists, who are its real subject, but then mentions several parties who according to them were not responsible for blowing up America, like the Klan or Skin heads (p. 172). Baraka presents his argument about terrorism in the following lines in which he refers to many acts of racism and discrimination in US history which he holds American terrorists accountable for even before anyone starts blaming foreign terrorists for the transgressions within its borders.

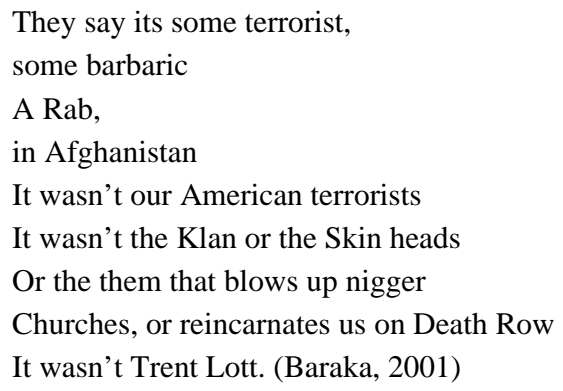

He challenges those who think it cannot be American terrorists causing the many tragedies in the USA by bringing back to the readers incidents from history that show US responsibility for the murder of many Red Indians, and lynching of "black people, [and] terrorized reason and sanity, Most of humanity, as they pleases". Baraka continues to give examples of the many violations the US has committed against humanity to support capitalism and serve its own interests.

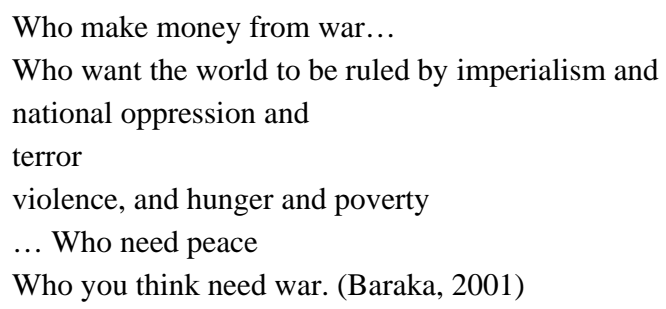


This poem is a critique of US policies that have been implemented but have only led to more oppression and destruction in the world. Baraka, as an intellectual exile, takes the liberty of exposing acts of evil caused by the US and raises questions about its role in creating war, terror, and fear when its citizens expect it to bring upon freedom and justice in other nations. He goes beyond the limits in criticizing presidential speeches about peace and war. He tries to unsettle others through the use of facts from history, which are eye openers, in the hope knowledge, critical thinking, and questioning authorities will lead to social transformation and more activism on behalf of the public.

The position the intellectual exile, such as Baraka, has chosen through living and writing, while there is no homeland to return to, can be intimidating for others as it grants the exile liberation from existing paradigms and society's restrictions. The exile can go anywhere with his/her thoughts beyond any limits set by authorities or governments. It is this freedom that unsettles others. In this sense, exile and marginality can be positive in the eyes of the intellectual. Said (1993) speaks of "the pleasure of being surprised", not taking things for granted, and dealing with instability that would most probably terrify others. Baraka is not afraid of pointing out America's wrong doing in terms of capitalism and the exploitation of workers, imperialism, and taking control of oil in foreign lands while preaching about good and evil. The claims he makes in his writing can be intimidating for those who have blind faith in their government and have never spoken truth to power. He enjoys the freedom the status of exile grants him to cross boundaries and break the silence. Baraka (2001) writes:

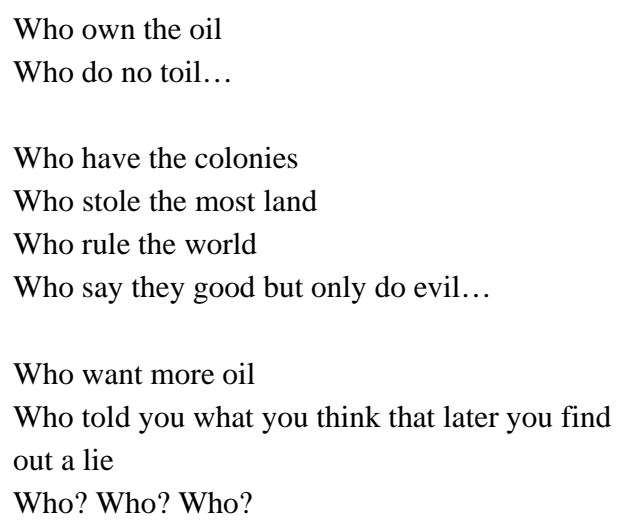

He denounces America's decisions to steal land and oil from other nations. He is disappointed in the country's role in the world as colonizer and ruler who allows itself to rule the world through violence, imperialism, terror, and hunger. The lines above demonstrate an exile's fearlessness of the restrictions set by authorities and insistence on speaking truth to power even if it means offending governments. It is this force with which an exile speaks that unsettles others especially officials working for the government. Ironically, this poem was not noticed much at first but later was labeled as anti-Semitic, and therefore, received many negative comments from politicians, journalists, poets, and critics (Gwiazda, 2004, pp. 480-482). Baraka's poem, in Said's (1993) words, has "moved [him] away from the centralizing authorities towards the margins" where he was able to see things "that are usually lost on minds that have never travelled beyond the conventional and the comfortable". Surely, this poem has not brought him closer to the mainstream or the prescribed path to follow, but brought him closer to the risky commitments he has made as an intellectual exile.

In "Reprise of One of A. G.'s Best Poems!”, Baraka (1979) condemns the USA for its indiscretions. He portrays it as "a butcher in a cowboy suit", an imperialist, and a capitalist that exploits its people. He stresses 
that “Capitalism/Is dying/ \& its killing, has killed/Too many”. In another stanza, Baraka (1979) addresses several issues that affect the lives of US citizens such as the class issue, poverty, and discrimination resulting in the fury of those troubled by the socioeconomic situation:

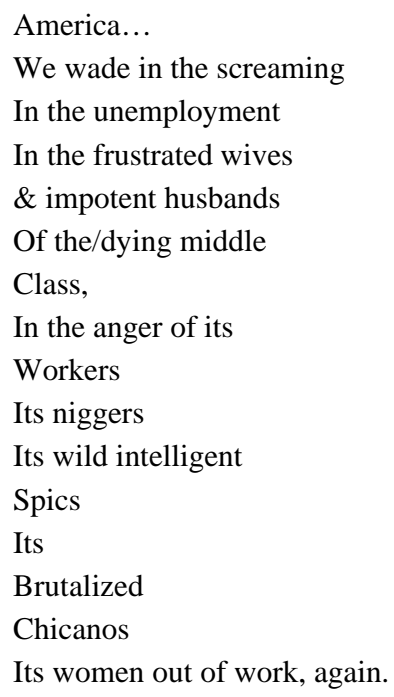

The previous lines reflect the voices of the marginalized in need of drastic change to end their poverty, exploitation, unemployment, and violence against some minorities. He highlights the distress Americans are undergoing whether they are workers, blacks, Chicanos, or women who are faced with the fact that the middle class is disappearing leaving the rich richer and the poor even poorer. He suggests:

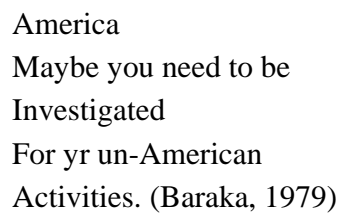

Baraka believes that the injustices inflicted on his fellow Americans and harmful practices seen in the land of the free are rather un-American thus need to be investigated. Ironically, the term "un-American" has taken on a new meaning, sine 9/11, which is the act of questioning the government. Baraka in these lines reveals the way America has turned against its own principles of freedom, equality, and justice and the very foundation it was built on through its un-American activities. He, repeatedly, turns US practice against itself by confirming it is the explosions and violence caused by the US in various parts of the earth that will actually get America to change. In his address to the USA which he refers to as "The Capitalists' Shangri-La”, Baraka (1979) declares:

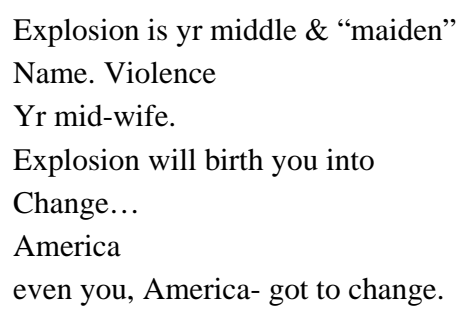

The writer, dissatisfied with America's continuous resort to violence and weapons, warns that through an 
explosion or extreme act, change will be brought about to the US. He emphasizes that change is necessary and, in fact, a must even for America, the super power in the world. Unfortunately, the way America is portrayed in this poem is hardly different from that in "Somebody Blew up America" although the two poems are over 20 years apart. He still sees it as a butcher killing and exploiting others to protect its capitalist and imperialist interests.

\section{Suheir Hammad "Breaks Barriers of Thought and Experience"}

Suheir Hammad immigrated to the U.S with her family as Palestinian refugees. She grew up in Brooklyn and was never formally trained as a writer, yet she published her poetry in Born Palestinian, Born Black (1995), Drops of This Story (1996), Zaatar Diva (2005), and Breaking Poems (2008) (Knopf-Newman, 2006, p. 71). Hammad, as a Palestinian American poet and activist, performs her poetry all over the world. She has won several awards such as the Audre Lorde Writing Award, The New York Mills Artist Residency (1998), The 2001 Emerging Artist Award, Asian/Pacific/American Studies Institute at NYU, and the Tony Award. She was also the original cast member and writer for Russell Simmons Presents Def Poetry Jam on Broadway (2003) (Knopf-Newman, 2006, p. 71).

Hammad states that the entire history of displacement and refugee crisis of the Palestinians was the narrative she had inherited from her Palestinian parents but when she went to school, the whole narrative was totally non-existent and was replaced with an entirely new one that portrayed Palestinians as violent and anti-Jewish. That is when she realized that the stories she heard about other people and their histories like the Puerto Ricans, Blacks, and poor White kids she grew up with all came from that same authoritative voice that gave her inaccurate information about her parents’ history (Brown \& Hammad, 2006). Perhaps this is when Hammad got interested in learning about the others' story as they would all share the same history of oppression and injustice and take on the responsibility of engaging in political activism and social reform. It is this realization that gave shape to her literary production throughout her career.

Hammad has experienced her fate, as an exile who is on a sacred mission, and "not as a deprivation and as something to be bewailed, but as a sort of freedom, a process of discovery" (Said, 1993). As an exile, she has broken barriers with her writing, penetrated cultures, and built bridges between them connecting the suffering of many nations. She does not see her fate as a deprivation but as a cause to fight for, resist submission, and reach out to others. It gave her the freedom to step out of the Arab American community and enter many others of various ethnicities and build solidarity with those subjugated and silenced across oceans.

For the intellectual, Said (1993) explains, an exilic displacement means being liberated from the usual path that dictates you honor typical footsteps taken to obey and follow the rules and do well at the job.

Exile means that you are always going to be marginal, and that what you do as an intellectual has to be made up because you cannot follow a prescribed path. If you can experience that fate not as a deprivation and as something to be bewailed, but as a sort of freedom, a process of discovery and doing things according to your own pattern as the particular goal you set yourself dictates, that is a unique pleasure.

Hammad is determined "to give voice to the voiceless" and to unsettle her readers by revealing all kinds of oppression in her writing. She often writes about similarities of people of color and their shared history of oppression that unites them. She strengthens the ties between those trying to survive their multiple struggles such as African Americans who have experienced many injustices living under White male supremacy (Brown \& Hammad, 2006). The exile, like Hammad, has a double perspective and never sees things in isolation but as 
an observer looking inside at the worlds he has encountered and those created in his own writing. Hammad's attachment to the black community is visible in her writing in the topics of race and segregation she touches upon in addition to the commitment she showed in her support of the victims of Hurricane Katrina. Her sympathy with the victims manifested itself when she held a benefit to raise funds for the survivors of the Hurricane under the title "Refugees for Refugees". She had put up a poster with the definition of the word refugee.

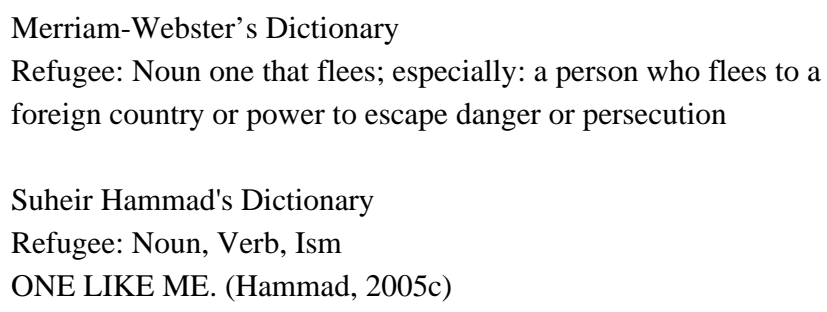

Hammad had chosen this definition to connect the Palestinians with the victims of the Hurricane who were abandoned and got no assistance from the state. They have both experienced the status of refugee and know what it feels like to be perceived that way by others who may have never been through anything remotely related to being a refugee or an exile. She is angered by officials who are passive and indifferent to the disasters that affect others.

In her poem, “A Prayer Band”, Hammad (2005a) reiterates the victims' concerns about the way their displacement was dealt with as if it were an irrelevant event taking place in the Third World. She reminds her readers that the negligence with which New Orleans was dealt with has occurred within the US to US citizens, but it did not get to the top of the government's priority list because it mostly affected African Americans and the poor. Hammad reveals the racism with which African Americans and their issues are handled by government officials. As an intellectual exile, she is not accustomed to being silenced, or belonging to a single community to defend, but seeks opportunities to reach out to the marginalized and oppressed no matter what their ethnicity is. However, in this case she has great loyalty to the African American community as it played a major role in her life since childhood and she sees its suffering as her own. Hammad (2005a), sarcastically, comments:

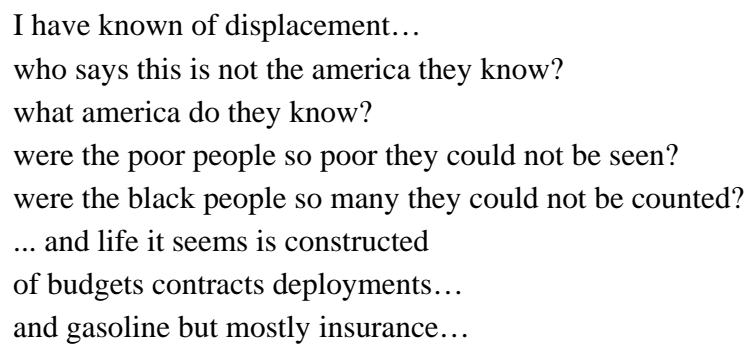

Hammad states that she is familiar with displacement having a Palestinian background which enables her to fully comprehend the situation in New Orleans where people were evacuated and uprooted by Hurricane Katrina. She criticizes the Bush administration for the way the victims of the hurricane were neglected and believes it is all due to the issues of race and class. She condemns it for its lack of action when assistance was urgently needed for American citizens who were struggling for survival. She realizes that life is all about the haves and not the have-nots who have lost everything as they were being displaced by the hurricane. Hammad 
finds it outrageous how materialistic and inhumane the US has become as the victims were left to drown because they were poor and black. Majaj (2004) writes:

[Hammad] is not interested in making anyone comfortable, least of all herself. Yet her writing is imbued not only with rage and grief, but also with a fierce insistence on affirmation and change... Poetry becomes, in Hammad's hands, a political tool, one used for critique, self-definition and empowerment. (pp. 260-261)

Hammad, as an exile, takes stances on critical issues such as Hurricane Katrina and 9/11 even if it makes her unpopular and entails taking risks like criticizing the government. Her activism is always focused on human rights, freedom, and positive change.

In "First Writing Since", Hammad (2001) responds to 9/11 and its impact on Arab Americans such as herself. She is aware of the danger awaiting anyone Muslim, or of Arab or Middle Eastern descent because of the hostile rhetoric used against them after the attacks as bombings in the past were associated with these people even before evidence was found to convict them. She writes, "Please god, after the second plane, please, don't let it be anyone who looks like my brothers". This is when her multiple affiliations appear but her connection to Arabs and Muslims becomes problematic yet there is no denying of such connection that makes her heritage and who she is today. The plurality of vision Said speaks of is reflected in Hammad's comments on the feelings some Americans experienced post 9/11 that could lead to further revenge and political turmoil. She looks at the situation from multiple perspectives that allow her, as an intellectual exile, to see simultaneously the horrific impact of the tragedy on America and the consequences other nations will have to endure from that moment on.

On my block, a woman was crying in a car parked and stranded in hurt.

i offered comfort, extended a hand she did not see before she said,

"we're gonna burn them so bad, i swear, so bad." my hand went to my

head and my head went to the numbers within it of the dead Iraqi

children, the dead in nicaragua. the dead in rwanda who had to vie

with fake sport wrestling for america's attention. (Hammad, 2001)

Hammad's exilic status entitles her to take an interest in humanity and the whole universe as she has become a citizen of the world and not of a single land thus her connection to human suffering wherever it may be. In the stanza above, she underlines the horror in the killing of children and builds a connection between the dead and oppressed in Iraq, Nicaragua, and Rwanda. She identifies with them and rejects the atrocities taking place in these nations. She shifts back to her affiliation to the US when she states she lives there, and "these are my friends and fam,/and it could have been me in those buildings, and we're not bad/people, do not support America's bullying”. She stresses that no matter what Americans did, still those who died on September 11 were victims and could have been her family or friends who do not deserve to die the way many did. Nevertheless, she condemns America's bullying and criticizes it for its foreign policies which have created many enemies for them around the world. The shifting back and forth between her dual identity and multiple affiliations becomes necessary in the next few lines because, in these circumstances, she cannot afford being confused with the enemy neither can she give up her connection to Arabs and Muslims who look like her brothers.

one more person ask me if $\mathrm{i}$ knew the hijackers...

one more person assume no arabs or muslims were killed.

one more person assume they know me, or that i represent a people.

or that a people represent an evil... (Hammad, 2001) 
She is infuriated by the thought of being associated with hijackers just because she has Arab roots and this is when she disconnects herself from belonging to that group of people who do not represent her or all Arabs and Muslims. She then reminds the readers of the fact that several tragedies were caused by Americans, but it did not lead to the generalization that all Americans or Christians are bombers like Mcveigh who was held responsible for the Oklahoma city bombing. "We did not vilify all white men when mcveigh bombed Oklahoma". She also refers to the crimes committed by KKK that are not stressed enough when issues of "holy books and hooded men" arise. These are references to violence taking place within the US by Whites and had nothing to do with Arabs or Muslims. Hammad goes on to present a more humane image of Palestinians and Arabs in contrast to the stereotypical one circulated by the media that represents them as heartless terrorists. She writes, "if there are any people on earth who understand how new york is feeling right now, they are in the west bank and the gaza strip" (Hammad, 2001). She humanizes Palestinians in these lines and asserts that it is they who would definitely understand and empathize with the $9 / 11$ victims because of all the crimes and human right violations committed against them. These people experience 9/11 on daily basis and many refuse to hear about their suffering. In this sense she connects the suffering of Americans and New Yorkers, particularly, with that of people in the Third World who have frequently experienced violence and bombings in their countries due to colonization and imperialism.

Hammad, as an intellectual exile, calls for critical thinking in the hope that the public will realize the polarization and ideologies created post $9 / 11$ to silence dissident voices that may question government decisions. She tries to open the reader's eyes to the radical nature of the former president's vision and stance that draw an unreasonable picture of the world where things are black and white and nothing in between. Hammad is critical of his speeches that invite people to choose one radical side over the other, both leading in the end to more massacres, wars, and tragedies in the world. She asserts, "either you are with us, or with the terrorists"-meaning keep your people/under control and your resistance censored, meaning we got the loot/and the nukes (Hammad, 2001). This is the very rhetoric Hammad rejects. It is George Bush's rhetoric of oppression through which he sought to control people and the stances they took on political issues. She condemns this dominance over people's thinking, resistance, and freedom of expression. Although she exposes the government's transgressions, she does not forget to mention the good in people. She shows faith in the goodness and kindness of Americans and believes that evil could never prevail as long as there are others like her who are dedicated to justice and human rights, and act against oppression and "hateful foreign policies".

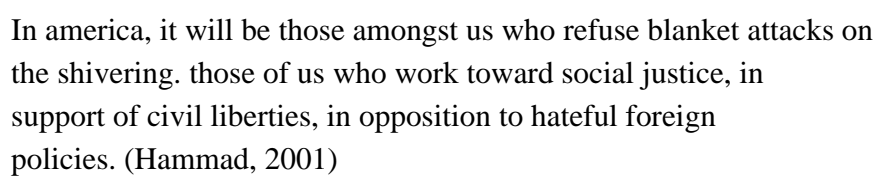

Hammad, as an intellectual exile, inspires her readers to get involved in acts that support justice, and encourages activists to resume efforts to achieve social transformation. She empowers them by showing solidarity and confirming that there are many conscientious Americans who cannot accept oppression as a norm and will continue to work against injustice and crimes against humanity.

\section{Conclusion}

Baraka and Hammad have both tackled issues of oppression and suffering within the US and outside its borders. They have brought to the foreground the universal injustices inflicted on the powerless by imperialist 
and hegemonic forces and given expression to many silent voices crushed by various political and social systems. They believe it is their responsibility as intellectual exiles to do so as it is a moral obligation to call for human rights.

Both poets encourage their readers to step outside the privileged lives they live and experience the suffering of others. They call on their own communities to transcend their own oppression and join others in their struggle and battle for freedom. They urge them to defend human rights as it is a universal cause that goes beyond the dilemmas of a single community and serves humanity at large. Through their writings, Baraka and Hammad have not allowed their position in the margins and outside the mainstream define them. On the contrary, they have taken advantage of their rather misfortunate situation and turned it into a source of creativity, art, empowerment, and activism. Actually, it is their exilic status that assisted them in building dreams for themselves and for the oppressed and exiled all over the world. They were able to make a difference in multiple communities, within the East and the West, by building solidarity between its citizens in addition to the big bang they created in the literary world.

\section{References}

Baraka, A. (1969). “Black Art”. In Black magic: Collected poetry (1961-1967). Indianapolis: The Bobbs- Merrill co.

Baraka, A. (1979). “Reprise of one of A. G.’s Best Poems!”. In Selected poetry of Amiri Baraka LeRoi Jones. NY: Morrow.

Baraka, A. (2001). Somebody blew up America. Retrieved from http://archive.adl.org/anti_semitism/baraka_poem.html

Brown, C., \& Hammad, S. (2006). Interview with Suheir Hammad. Retrieved from http://electronicintifada.net

Buruma, I. (2001). The romance of exile-Real wounds, unreal wounds. Retrieved from http://business.highbeam.com/4776/article-1G1-71118896/romance-exile-real-wounds-unreal-wounds

Gery, J. (2011). Duplicities of power: Amiri Baraka’s and Lorenzo Thomas’s responses to September 11. African American Review, 44, 167-180.

Gwiazda, P. (2004). The aesthetics of politics/the politics of aesthetics: Amiri Baraka's "Somebody Blew up America". Contemporary Literature, 45(3), 460-485.

Hammad, S. (1996). Born Palestinian, born black. New York: Harlem River Press.

Hammad, S. (2001). First writing since. Retrieved from http://www.inmotionmagazine.com/ac/shammad.html

Hammad, S. (2005a). “A Prayer Band”. In Logos: A Journal of Modern Society and Culture. Retrieved from http://www.logosjournal.com/issue_4.4/poetry_4.4.htm

Hammad, S. (2005b). “Mike Check.” In Zaatar Diva. New York: Cypher Books.

Hammad, S. (2005c). Refugees for refugees: Benefit for Katrina survivors. Retrieved from http://insaf.net/pipermail/nyfoil-__insaf.net/2005q3/000569.html

Hartman, M. (2006). This sweet/sweet Music: Jazz, Sam Cooke, and reading Arab American literary identities. MELUS, 31(4), 145-165.

Italie, H. (2014). Amiri Baraka dead: Controversial author and activist dies at 79 . Retrieved from http://www.huffingtonpost.com/2014/01/09/amiri-baraka-author-activist-dies-79_n_4570912.html

Jacobs-Huey, L. (2006). The Arab is the new nigger: African American comics confront the irony and tragedy of September 11. Transforming Anthropology, 14(1), 60-64.

Knopf-Newman, M. (2006). Interview with Suheir Hammad. Melus, 31(4), 71-91.

Majaj, L. S. (2004). Visions of home: Exile and return in Palestinian-American women’s literature. Thaqafat, 7(8), $251-264$.

Majaj, L. S. (2008). Arab-American literature: Origins and development. American Studies Journal, No. 52

Richardson, J., \& Baraka, A. (1989). Interview with Amiri Baraka. Retrieved from http://digital.wustl.edu/e/eii/eiiweb/bar5427.0106.009amiribaraka.html

Said, E. (1993). The Reith lectures: Intellectual exile, expatriates and marginals. Retrieved from http://www.independent.co.uk/life-style/the-reith-lectures-intellectual-exile-expatriates

Said, E. (2002). Reflections on exile and other essays. Cambridge: Harvard University Press. 